\title{
Russia/Nigeria Diplomatic Ties: An Historical Perspective
}

\author{
Abimbola Damilola Waliyullahi \\ Post Graduate Student, Department of European Studies (Russian) \\ University of Ibadan, Ibadan Nigeria
}

doi: 10.19044/esj.2016.v12n1p323 URL:http://dx.doi.org/10.19044/esj.2016.v12n1p323

\begin{abstract}
The Diplomatic relations between Nigeria and USSR (Union of Soviet Socialist Republics) now Russia started over 55 years ago. Russia, being the legitimate heir to the USSR in 1961, opened its Embassy in Lagos with Ambassador Feodor Pavlovich Dolya as the Head of the Mission, Nigeria reciprocated in 1962 in Moscow with Ambassador C.O Ifeagwu as the Head and till this day, both countries have maintained cordial political, economic and cultural relationships but not without some disagreements. However, Soviet involvement in Nigeria, just like in many other African countries diminished greatly in the wake of Mikhail Gorbachev's perestroika (reconstruction) of the middle 80s. With the Cold War continuing and the Soviet economy in shambles, the USSR had little incentive to continue its active presence in Africa. By the time of Soviet Union disintegration in 1991, the country had lost much of its influence and prominence in Nigeria and Africa. Nigeria is a focus of this paper as this article examines Russia/Nigeria diplomatic ties from the historical point of view relying on diplomatic theory as a tool to trace the existing diplomatic ties between the two countries.
\end{abstract}

Keywords: Ties, Economic development, social political, challenges, prospects

\section{Introduction}

The collapse of the Soviet Union was a great blow to the hopes and aspiration of the revolutionaries, the union came to an end in December 1991 following years of efforts to manage the growing domestic challenges of communist autonomous enclaves with the pragmatic program of glasnost (openness) and perestroika (reconstruction). As a result, republics of Armenia, Kazakhstan Azerbaijan, Kirgizia, Georgia, Byelorussia, Moldova, the Russian Socialist Federation, Tajikistan, Turkmenistan, Ukraine, Uzbekistan and the troublesome Baltic states of Estonia, Latvia and 
Lithuania assumed independent status within the Commonwealth of Independent States (CIS).

The Soviet state, marked throughout its brief but tumultuous history by great achievement and terrible suffering, died today after a long and painful decline, It was 74 years old. Conceived in utopian promise and born in the violent upheavals of the "Great October Revolution of 1917," the union heaved its last in the dreary darkness of late December 1991, stripped of ideology, dismembered, bankrupt and hungry but awe-inspiring even in its fall. (The New York Times, December 26, 1991)

(Agubamah: 2014 pg 194) agreed that the disintegration of Soviet Union led to the collapse of the world socialist system, the Warsaw Pact and the Council of Mutual Economic Assistance (CMEA). With that also went the grand foreign policy posture of the Soviet Union as a Superpower and a pillar of support for developing countries in an International environment dominated by ideological polarization and the cold War. The collapse of the Soviet Union led to crises of a new world order, and Eventually what many considered the triumph of capitalism in the Competition with communism and the beginning of a new phase of capitalist Development generally referred to as globalization.

With a strain in Russian American /EU relations at its lowest ebb, not seen since cold war era, economic embargo on Russia over the annexation of Crimea and proxy war in east Ukraine (Lugansk and Donetsk) biting harder economically, the downing of Russian airliner in Egypt and war plane in Syria by ISIS and turkey, a lot has changed in the dynamics of International relations, different actors with different agenda. Vladimir Putin led a resurgent and energetic Russia has moved from a mere regional power to the new super power over his role on the world map.

\section{Theoretical framework}

This research work used Traditional diplomacy which basically relates with territory, it is based on the assumption that communities are organized in the sovereign nation-states and the borders and limits are clearly defined, the theory is known as traditional diplomacy because it is more comfortable with geography and territory. The world where territory is no more a defining principle does not need the implications of traditional diplomacy.

For effective performance, there are some necessary qualifications for traditional diplomacy, Hedley: 1997 in Agubama 2014 opined that there 
must be more than one state; these states must be sovereign political units, able to exercise supreme Authority within, and independence out side the unit. The second qualification is the existence of shared values and interests, which allow states to develop some regular pattern of interaction.

Sharp (2009) agues that the demand for diplomacy, and the need for the insights of diplomatic theory are on the rise, he identifies a diplomatic tradition of international thought premised on the way people live in groups, the differences between intra- and inter-group relations, and the perspectives which those who handle inter-group relations develop about the sorts of international disputes which occur.

It is a fact that the fundamental tenets of sovereignty, national interest, and national security lie at the heart of traditional diplomacy and this is the main objective of Nigeria and the Russian federation, traditional diplomacy was more formal and protocols were extended to show the goodwill gestures, Russia/Nigeria diplomatic relations are centered on state relations and the justification for the use of traditional diplomacy theory.

\section{Nigeria- russia's relation in retrospects}

November 25th, 2015 was exactly 55 years since Nigeria and USSR (Union of Soviet Socialist Republics), now Russian federation established diplomatic relation with Nigeria, though, Soviet Union opened its Embassy in Lagos in 1961, Ambassador Fedor Pavlovich Dolya was the Head of the Mission, Nigeria opened in Moscow in 1962 with Ambassador C.O. Ifeagwu as the Head of the mission. Both countries have since then always maintained cordial political, economic and human relationships, but not without some challenges.

Beyond Nigeria, the involvement in Africa of the Soviet Union for which Russia is the principal successor state came on the heels of the continents political independence. During the 60s and 70s, the Soviet Union was a critical partner to Africa, especially in giving drift to the anti-colonial and antiapartheid Rule in the continent. Even though, not all the freedom-fighters of the continent share the Soviet communist ideology, nevertheless, there is no doubt that the moral, material and political support for Africa contributed in no small way to the eventual collapse of colonialism in the continent (Obasekola, 2011)

Meanwhile, the central Authority in Nigeria announced non alignment in her foreign policy with the outside world after independence in 
1960 because she does not want to be diplomatically tied to either the western or the eastern power blocks even though she was still tied to Great Britain, her colonial master (Olatunde: 1976)

As at 1960-1966, the county's ruling class was openly pro-west, after diplomatic relations were established, Nigeria limited the size of the Soviet mission and was reluctant to accept aid. Nigerian ruling elites were mostly anti-Soviets; nevertheless, there were some political and organized labour elites who agitated for a closer tie with Russians. Communist literatures were banned and no Nigerian students were cleared to study in Moscow except those who found their ways to Soviet Union by passing through Nigeria's neighbouring countries. Under the leadership of Sir Abubakar Tafawa Balewa, US maintain limited contacts and encourage the development of a non-alignment foreign policy. USSR reacted cautiously to the series of political crises which plagued Nigeria during its early years of independence. (Olatunde: 1976)

In 1965 the country was on the verge of anarchy and disintegration as a result of the violence and general strike ensuing from the 1964 general elections crisis. Probing further, despite her advantage as a super power, Russia did not utilize revolutionary communism Situation to promote chaos but a symbiosis and pragmatic relationship. (Obasekola: 2011)

There was a counter-coup on August 1 1966, with General Yakubu Gowon as the new Nigerian leader, Cautiously the Soviet Union welcomed the new regime, with the released from prison of Chief Obafemi Awolowo, serving a prison term for treason. Awolowo and his Action Group party had been sympathetic to a closer pragmatic tie with the Soviet Union. Moscow also fancied the stance of the new Gowon regime on federal structure of the Nigerian state. (Olatunde: 1976)

Obasekola (2011) agreed that, the new stance of Russia on Nigeria and Africa in general was not however, unconnected with the exit of Comrade Nikiti Khrushchev from the helms of affairs in Russia in 1964; the Soviet quickly denounced his policy approach to foreign affairs, a more balanced and less ideological approach was promulgated, towards the late 1960s, the Soviet leadership became less interested in revolution in African states and more interested in the political support of those states in their struggle to find their space in the international affairs and in the economic benefits of mutual cooperation irrespective of the nature of their internal regimes.

This new Soviet pragmatic foreign policy enabled them to take the side of the Federal government of Nigeria when Col Odumegwu Ojukwu in May 301967 proclaimed secession of the Eastern Region of the country to 
form a sovereign Republic of Biafra, and civil war ensued in July 6, 1967, the demands of the civil war forced the Federal Government of Nigeria to court USSR.

While the civil war rages, Col Gowon sent a special envoy to Kremlin to explain government's position on the unraveling crisis and to inform the Soviet leadership his administration desire to maintain and develop the friendly relation with the USSR, during the visit, a practical discussions based on increased trade between the two countries were made. Such mutual trust and respect between the two administrations during these periods yielded a remarkable improvement in relationship of the two countries. (Obasekola: 2011)

When civil war broke up, it offered Moscow an opportunity to become a primary arms supplier to the federalists throughout the conflict. Nigeria needed Russia's diplomatic and military support in its war efforts to defeat the secessionists. Russian involvement, on the side of the Federalists, introduced another momentum to the conflict; it afforded Nigeria to cultivate and widen diplomatic ties with the Eastern bloc, thereby given more substance to its non-alignment foreign policy.

Obasekola (2011) submitted that, during the civil war, France and China sided with the Biafra, while Britain and USSR backed the Federal side, United States assumed cautious neutrality, the political dividends that accrued to Soviet Union as a result of siding with the Federal side could not be compared with those gained from similar roles in some of the other major conflicts in Africa; certainly there was a new impulse in Russian-Nigerian relationships.

In this context, Nigeria's relations with the USSR, after the end of the civil war in 1970, were clearly based on the pursuit of practicality over aesthetic qualities (pragmatism).

When the civil war ended, political, economic and social pacts with USSR became more promising. Soviets made Machines and Equipments (Cars, agricultural equipments and tools) and home appliances found their market in Nigeria. Aeroflot Airlines started to operate constant commercial flight to Lagos. Russians became respectable in Nigeria, most especially for their scientific achievements, which earned them successes in space technology and ammunitions. (Obasekola: 2011)

Numerous joint documents have since been signed between Nigeria and Soviet (Russia). These documents include Agreements on an air communication (1967), agreement on economic, scientific and technical cooperation (1968), Agreement on cultural and scientific cooperation and exchanges (1970), Protocol on the equivalence of scientific degrees, diplomas and certificates issued and awarded by the educational institutions of the parties (1973), Agreement on economic and technical cooperation in 
the construction of a new metallurgical enterprise in Nigeria (1976), Trade agreement (1987), Agreement on the establishment of intergovernmental commission on trade, economic and scientific and technical cooperation (1989), Protocol on political consultations (1990), and Agreement on cooperation against illegal drugs and Psychotropic substances (1999). These agreements have led to different degrees of Soviet (Russian) involvement in Nigeria's metallurgy, petroleum industry, geological surveys, public health services and personnel training. Two systems of oil pipelines of $920 \mathrm{~km}$ with total output of 18.7 million tons per year were constructed by the USSR in 1977 - 1982 on conditions of general contract in Nigeria. (Obasekola: 2011)

Russian technical assistance in the geological survey works on metallurgical raw material (iron ore, coal, and non-metallic raw material) was carried out in 1971 - 1983. A metallurgical complex including technical school for 652 pupils and Technical Training College for an iron and steel industry for 1325 pupils was established in 1975 in Nigerian town of Warri. In cities across Nigeria, a group of Russian medical doctors worked during 1971-1980, Russia has contributed a lot to the educational development of Nigeria, and More than 10 thousand Nigerians have received education in USSR/Russian educational institutions since 1960s.

A metallurgical plant was established in Ajaokuta to boost the industrial base of Nigerian economy; bilateral trade reached its peak in 1988 at a sum of about 184 million US Dollars. (Obasekola: 2011)

However, Soviet involvement in Nigeria, just like in many other African countries diminished greatly in the wake of Mikhail Gorbachev's perestroika (reconstruction) of the middle 80s. With the Cold War waning and the Soviet economy in shambles, the USSR had little incentive to continue its active presence in Africa. By the time of Soviet Union dissolution in 1991, the country had lost much of its earlier clout and prominence in Nigeria and Africa. (Olatunde: 1976)

\section{Benefits of russian-nigeria relations}

Aranmolate (2009), in an unpublished keynote address affirmed that Russia is a nation with efficient infrastructures, roads, rails shipping energy and aviation but laments that the country has never had it so good like her European money bag ( Russia), Nigeria has a lot of opportunities and it is one of the most important investment destinations in Africa and the world.

Nigeria and Russia has a combine population of over 350 million people, there is the need to expand the scope of cooperation in the areas of education, science and technology and defense sector by creating conducive environments for Russian and Nigerian students and Artisans willing to study in Russia and those willing to study in Nigeria.

(Russian Academy of Sciences: 2015) 
Bottom of Form

Among the investment in Nigeria originating from Russia, we can also mention an interesting Russian-based financial-investment consultancy Group, Renaissance Capital. Renaissance Group began operations in SubSaharan Africa in 2006, from its operational office in Lagos, Nigeria. (Russian Academy of Sciences: 2015)

Jan 15, 2007 - The Nigerian-Russian Business Council was officially established with an aim to promote cooperation, collaboration and improvement of trade (The Nation: 2007)

In March 2009, Nigerian Foreign Minister Ojo Maduekwe visited Moscow to have talks with his Russian counterpart, Lavrov and had meeting with President Medvedev. Agreements were reached on activating the realization of the potentials both countries have in the trade and economic spheres, including execution of projects in infrastructures, ferrous and nonferrous metals industry, electric power generation, and nuclear energy. (Sputnik news: 2008)

On June 24th, 2010, for the first time in the annals of the RussianNigerian relation, a Russian leader paid state visit to Nigeria. President Dmitry Medvedev during his visit to Abuja had meetings and talks with his Nigerian counterpart, President Umar Musa Yar’Adua (now late); at the end of which six bilateral agreements aimed at boosting both nations' strategic partnership were signed. The agreements are on Investment promotion and Protection of Agreement (IPPA); Cooperation in the field of nuclear energy for peaceful purposes- (BBC news: 2010)

In the educational sector, more than fifty government scholarships are being awarded annually to Nigerian students while many sponsored themselves to Russia to study (Poliyakov: 2009)

As the nation under the leadership of President Goodluck Jonathan seeks for a definite solution to the seemingly unending Boko Haram attacks, President Jonathan has pitched tent with the Russian government to help the nation fight terrorism as both nations signed a memorandum on interaction and cooperation between their security councils. (The Herald: 2014)

Recently, relations of Russia with Nigeria have been developing steadily. Many Russian companies are implementing or preparing to storm Nigeria, a number of major investment projects in such areas as energy, hydrocarbon extraction, metals and farm mechanization. Long-term prospects include collaboration in the peaceful uses of atomic energy and in space exploration. (Obasekola: 2011)

As at 2008 despite the global economic downturn, there was growth in the volume of trade between Nigeria and Russia which doubled in that year to $\$ 300$ million, according to the Central Bank of Nigeria, this figure was put at $\$ 1.5$ billion taking into consideration other indirect transactions 
between the two economies. Though, Nigeria firmly holds second place among the sub-Saharan African countries in trade with Russia, but given the potentials of the two countries (CBN 2008)

Russia and Nigeria are cooperating in a joint venture to exploit Nigeria's vast gas reserves. Russia's state-owned Gazprom has signed a $\$ 2.5 b n$ (£1.53bn) deal with Nigeria's state operated NNPC, to invest in a new joint venture to develop, extract and transport gas from Nigeria's fields, The agreement comes during a four-day African tour by Russian President Dmitry Medvedev, the contract, when fully honored will lead to the exchange of ideas and engagement of Nigerian armies of jobless youths. (BBC NEWS: 2009)

The Nigaz deal would lay the foundations for building nuclear power reactors in Nigeria that has previously said it would like to develop a nuclear power plant to address its energy shortages.

There is Memorandum of understanding between Russian Space Agency and Nigeria's National Space Research and Development Agency (NASRDA), under the agreement, Russia will provide the human capacity building for Nigeria to achieve her plan to launch the first satellite outer space between 2015 and 2018. It is a fact that Russia landed the first man in space, Yuri Gagarin in 1962, and in 2007 Nigeria's SAT-1 was lunched from a Russian cosmodrome (Nigerian tribune: 2007) and it marked the beginning of Nigerian presence in space, a reason to learn the Russian language to strengthened future agreements and provide employment opportunity for her citizens and enhance scientific and literary research in academic institutions

It must have by now dawned on those who rely only on American support for existence or retention of political power that free cups of coffee are no longer free in the white house given the manner in which Nigeria was turned down when she seeks help to combat terrorism. That unilateral action confirms the saying that in international relations, 'there are no permanent friends and no permanent enemies but permanent interest''- (John Foster Dulles)

United States of America (USA) refused to sell weapons to Nigeria to combat Boko Haram insurgents and cancels military training agreements she entered into with Nigeria, alleging human right abuses at the front, Nigerian government led by Dr Goodluck Jonathan looked eastward to the Kremlin for training and supply of military hardware.( VOA news, 2014)

'Nigeria has turned to Russia to buy heavier weapons following a recent strain in relations with the United States. After the U.S. rejected a request for Cobra attack helicopters, Nigeria cancelled a U.S. military training program linked to the fight against Boko Haram militants. Analysts now are weighing 
the effects of the arms deal with Russia'’. (Joe

Decapua, VOA, Dec, 10, 2010)

\section{Challenges and Recommendations}

Diplomatic relations between Nigeria and Russia has not been without its low moments. One of such moments was when some sailors, who were in the crews of a Greek-owned ship MT African Pride, charged for oil bunkering, illegal possession of Nigerian oil and economic sabotage, for which the punishment is death penalty, There were prolonged delays in the sailors' trial, which prompted protests from Russian government and strained diplomatic relations with Nigeria. Although, the sailors were eventually convicted by Nigerian court and each received six-month suspended sentences as part of a plea bargain, at the end, they were released because they have already spent nearly two years in pre-trial custody of the Nigerian Law Enforcement Agency. (Daily post: 2013)

Another awful moment in the friendships was in June 2007 when 6 Russian employees of Russian Aluminum Company (RUSALC) were abducted by the militants in the volatile Niger-Delta Region of Nigeria. After a long stay in captivity, the men were eventually rescued safely by a combined team of Nigerian Army and Police in August 2007. (Vanguard: 2007)

It was reported in Moskovsky Komsomolets daily of November, $24^{\text {th }}$, 2011 that a, Nigerian student, Mr. Akinola Olufemi, was found stabbed to death in southern Moscow with his ears cut off in a grisly murder, the victim was a student in the northern city of Arkhangelsk and that the crime appeared not to have been a robbery as his papers and wallet were left at the scene, the incident led to a strain in Nigerian Russian relations.

Nigerians and Russians are friendly and sympathetic to each other. There are lots of Joint-Ventures involving private Nigerian and Russian businesses, operating on their level without any involvement of their governments.

The nation newspaper reported back in June 2015 about "Olalusi O. Victor, a Nigerian who led a team of other International students from Russia, Italy, Greece, and Morocco and bagged the "Best Captain of the Year” award at the University's annual Quiz competition. His team International United - won Silver at the University's annual Quiz competition”.

Nigerians are perceived to be brilliant, hard-working, intelligent and pleasant people in Russia, although not without exclusions. They have always been among the best minds in Russia, over the past five years, Nigerian students at the Russian National Research Medical University have consistently topped the graduation chat, bagging honours and contributing 
their wealth of knowledge to the University’s academic status.( the nation: 2015)

Many Russian women are happily married to Nigerians. Ironically, Russia and Nigeria share a lot of things in common; covering population, attitude, social vices, natural resources, multi-cultural and multi-ethnicity etc. both have also bitter experiences of social and political regimes. No wonder intermittently (arise) some domestic misconception and suspicion of each other.( Russian Academic of sciences:2015)

There is significant number of Nigerian elites, who are already bearers of Russian language and culture. Russia should be proud of them and patronize them for cross fertilization of ideas. This cooperation in human relations should be strengthened to pave way for more students and personnel to be trained in Russia. Implementation and utilization of all the already signed agreements, a friendly approach be applied in visa and immigration policies towards each other's citizens, another issue is the absence of neither Russian nor Nigerian Airline flying regular race to Russia.

Tourism is another area that can be explored, Russian holiday makers can tour Nigerian tourist sites like Obudu cattle ranch, Erin Ijesha water fall and many others instead of Egypt and Turkey to prevent Islamic state attack on her citizens while Nigerians can start visiting Sochi and the Crimean resolts. Beside leisure touring of Nigeria by Russians, they are also welcome as potential investors in the emerging tourism industry of the Nigerian economy.

There are many people of Nigerian extract contributing to Russian economy, not only by their professional skills, including in sports and entertainment, among them are Aleksandr Silvestrovich Alumona born 18 December 1983 in Moscow, Russia, a Russian footballer of Nigerian ethnic origin who plays for Isloch and Alice Edun a singer who is of NigerianRussian descent. (snipview.com)

\section{Conclusion}

In conclusion, Nigeria-Russia relations have come of age, despite some psychological differences and suspicions, there are lots of gains, the continued assistance in human capacity building (a quota of scholarships to Nigerians), Nigeria and Russia

Needs each other and has a lot to learn from each other given the similarity in their economic and human base.

Work is still needed to be done in the direction of media and cultural exchanges and some trade favorable policies on the part of Russian government to allow more Nigerian exports, while it is desirable that Nigeria and Russia move their bilateral relation to a new level of active cooperation in important and strategic economic sectors, both countries should take 
account of the disparity in capacities and ensure that this is not allowed to lead to lopsidedness and dependency, such as being witnessed in the economic cooperation with China, America, India and other developed economies.

The general view was that the current state of the bilateral relations between the two countries is weaker than it should be and supposed that the relations strengthening could be achieved by means of more active involving of the two states governmental bodies in their development, on the one hand, and making more emphasis than before on the development of cooperation at the level of small and middle-size business.

\section{References:}

Agubama Edgar- Nigeria- Russia Relations: After and Now, European Scientific Journal, 2014.

Analysts Weight Nigeria- Russia Arms Deal (Voice of America) VOA, December, 10, 2014

Aranmolate, S (2009): Russia and Nigeria, reasons for Mutual Cooperation. Keynote Address delivered at the Faculty of Arts, Russian Day. Unpublished paper

Business Insider, court strips Rusal of aluminum smelter assets, July 2012.

Buziness Africa, Nigerian Russian relations, Bashir Olalekan, Moscow (www.buzinessafrica.com/expertspolicy) retrieved $10^{\text {th }}$ august, 2012)

BBC NEWS, Gazprom seals \$2.5bn Nigeria deal (http://news.bbc.co.uk/2/hi/business/8118721.stm)

Daily post, 15 Russian sailors facing life imprisonment in Nigeria (//dailypost.ng/) retrieved on $26^{\text {th }}$ November, 2015

Moskovsky Komsomolets daily, November, 24 ${ }^{\text {th }}, 2011$

The New York Times, END OF THE SOVIET UNION; the Soviet State, Born of a Dream, Dies

SERGE SCHMEMANN, December 26, 1991

Sputnik news, Nigerian foreign minister due in Moscow for energy talks (http://sputniknews.com/) retrieved $26^{\text {th }}$, November, 2015)

Olatunde Ojo (1976) Nigeria-soviet relations, retrospect and prospects Nova science publishers, Inc

Poliakov Alexandria (2009) The two Giants (Nigeria and Russia) in the Face of Global Economic Meltdown: Exploring Options for Mutually Beneficial Cooperation being an unpublished paper delivered at the Faculty of Arts, Russian Day.

Paul Sharp, Diplomatic theory of International Relations, Cambridge University Press, 2009

Punch Newspaper, $1^{\text {st }}$ November, 2013: Maurine, Azuh Nigeria- Russia Move to Boost Trade Relations 
Segun Odunuga (1998) East European Revolution and Nigeria’s Diplomacy, Stirling-Horden Publishers (Nig.) Ltd The nation, Nigerian-Russian Business Council inaugurated (www.thenationonlineng.net/archive2/tblnews_Detail.php?id=8486) retrieved on $26^{\text {th }}$ November, 2015

The Nation newspaper, Nigerian students top in Russian University, June 22, 2013

News Watch Times, Nigeria-Russian Relationship: A friend in need, Kehinde Adegoke, December 14, 2014.

The Herald, Russia, Nigeria Sign Memorandum on Security Councils' Cooperation (http://www.theheraldng.com) retrieved on $20^{\text {th }}$, November, 2015

Vanguard, Militants Abduct 6 Russians, Kill one (www.vanguardng.com) retrieved, $30^{\text {th }}$ October, 2015 